\title{
Capital mercantil autônomo e a transição ao capitalismo: a polêmica sobre as duas vias e o papel das cidades ${ }^{1}$
}

Eduardo Barros Mariutti

Instituto de Economia / Universidade Estadual de Campinas (IE/UNICAMP)

Recebido: 09/05/2020 Versão revisada (entregue): 25/05/2020 Aprovado: 27/05/2020

\begin{abstract}
Resumo
Tendo como referência principal o clássico debate sobre a transição do feudalismo ao capitalismo, este artigo discute algumas das vias que o capital mercantil tomou para penetrar na "produção" e, desse modo, acelerar a formação do capitalismo. Deste ponto de vista, adentramos na polêmica sobre as duas vias para a gênese do capitalismo, que dividiu Maurice Dobb e Paul Sweezy, na década de 1950. Por fim, será discutida a acalorada controvérsia sobre o papel das cidades na formação do capitalismo, uma temática que exige a incorporação crítica das reflexões de Henri Pirenne ao terreno da discussão marxista. As cidades não devem ser vistas como um "elemento externo" ao feudalismo, mas como outra forma de autoridade e de institucionalidade, distinta daquela do feudo e das unidades institucionais da nobreza eclesiástica.
\end{abstract}

Palavras-chave | Capital mercantil autônomo; cidades; feudalismo; marxismo; transição ao capitalismo.

Código JEL | F02 N13 P19

\section{Autonomous mercantile capital and the transition to capitalism: the controversy over the two ways and the role of cities}

\begin{abstract}
Having as main reference the classic debate on the transition from feudalism to capitalism, this article discusses some of the paths that mercantile capital has taken to penetrate the sphere of "production" and, thus, accelerate the transition to capitalism. From this point of view, I will briefly discuss the controversy over the two ways to the genesis of capitalism, which divided Maurice Dobb and Paul Sweezy in the 1950s. Finally, I will discuss the heated controversy over

\footnotetext{
1 Uma versão inicial deste artigo foi publicada, sob o título "Capital comercial autônomo e a transição ao capitalismo: a polêmica sobre as duas vias e o papel das cidades", como "Texto para Discussão" [N. 227] junto ao
} Instituto de Economia, da Unicamp, em fevereiro de 2014.
\end{abstract}


the role of cities in the formation of capitalism, a theme that requires the critical incorporation of Henri Pirenne's reflections into the field of Marxist discussion. Cities should not be seen as an "external element" to feudalism, but as another form of authority and institutionality, distinct from that of the feud and the institutional units of the ecclesiastical nobility.

Keywords | Autonomous mercantile capital; cities; feudalism; Marxism; transition to capitalism.

JEL-Code | F02 N13 P19

\section{Capital mercantil autónomo y la transición al capitalismo: la controversia sobre las dos vías y el papel de las ciudades}

\section{Resumen}

Teniendo como referencia principal el clásico debate sobre la transición del feudalismo al capitalismo, este artículo discute algunas de las vías que tomó el capital mercantil para penetrar la "producción" y, por lo tanto, acelerar la formación del capitalismo. Desde este punto de vista, entramos en la controversia sobre los dos caminos hacia la génesis del capitalismo, que dividió a Maurice Dobb y Paul Sweezy, en la década de 1950. Finalmente, se discutirá la acalorada controversia sobre el papel de las ciudades en la formación del capitalismo, tema que requiere la incorporación crítica de las reflexiones de Henri Pirenne en el campo de la discusión marxista. Las ciudades no deben verse como un "elemento externo" al feudalismo, sino como otra forma de autoridad e institucionalidad, distinta de la del feudo y las unidades institucionales de la nobleza eclesiástica.

Palabras clave | Capital mercantil autónomo; ciudades; feudalismo; marxismo; transición al capitalismo.

Codigo JEL | F02 N13 P19

\section{Introdução}

O adjetivo autônomo é aqui atribuído ao capital mercantil para destacar o fato dele fundamentar-se necessariamente na separação entre a produção - engendrada por relações sociais variadas, porém geralmente distintas da integração pelo mercado e a esfera da circulação, na qual ele se situa e tende a dominar quase exclusivamente. Nos modos de produção onde ele incide é, exatamente, esta posição insular que o converte na função por excelência do capital e, portanto, em sua forma preponderante. Assim, a manifestação do capital mercantil pressupõe e simultaneamente reforça a separação entre o seu circuito e a "produção". O ponto decisivo é que, nestas condições, os produtos transacionados se convertem em 
mercadoria ao serem expropriados - das mais variadas formas, mas geralmente com algum grau de violência - para nutrir o capital mercantil ${ }^{2}$. É neste aspecto preciso que reside a sua autonomia. Mas, como esta forma de capital não consegue penetrar diretamente nos mecanismos de reprodução do trabalho e, principalmente, não é capaz de se apropriar da força de trabalho, a sua autonomia pode ser pensada também por oposição à sua forma "superior", isto é, o capital propriamente dito, que só se manifesta no modo de produção capitalista e, que, portanto, precisa incluir e simultaneamente negar o trabalho. Somente neste caso o capital pode se converter em valor que se autovaloriza e, simultaneamente, possibilitar a autonomização da esfera econômica, a qual, desde então, tende a articular todas as demais.

Esta formulação pode gerar desentendimentos. Algumas observações podem ajudar a esclarecer o que quero dizer. O termo economia aqui é entendido no seu sentido substantivo nos termos definidos originalmente por Polanyi, mas buscando reforçar os vínculos do seu pensamento com o Materialismo Histórico. Em cada modo de produção, uma esfera da existência social articula as demais: é a partir dela que se pode compreender a organização geral da sociedade. No capitalismo e isto parece ser uma de suas principais peculiaridades - é, claramente, a dimensão econômica que articula as outras. Não por acaso, somente a partir do capitalismo foi possível desenvolver a noção de uma ciência da economia. E a trajetória da constituição da dismal science ilustra claramente as formas de consciência do sinuoso e lento desenraizamento da economia das outras dimensões da realidade social. Sem isto, seria impossível sequer conceber a noção de economia e, portanto, muito menos chegar à noção de que a economia é dotada de lógica própria e que, supostamente, pode ser apreendida cientificamente, isto é, isolada das demais (o fetiche do economista).

Com isto, mesmo tendo como referência o capitalismo, não quero dizer que a economia determina diretamente as outras esferas ou que, por exemplo, a política (ou a cultura) é simplesmente uma emanação da economia. A forma como a economia articula as demais instâncias no capitalismo redefine a dimensão do político (algo que não necessariamente é captado pela importante, porém capciosa, noção de "determinação em última instância"). Na Antiguidade Clássica, por exemplo, dominava claramente a política: a "economia" era um meio de existência que favorecia a reprodução de uma organização social cujos princípios de ordenamento não eram plenamente compatíveis com a sociedade de mercado. Mutatis mutandis, o mesmo pode se dizer das sociedades "hidráulicas" (ou, em formulação mais próxima dos termos marxianos, baseadas no modo de produção asiático): eram os mecanismos de redistribuição organizados a partir de um poder central que davam coerência e articulação aos diversos setores que compunham a sociedade. $\mathrm{O}$

\footnotetext{
${ }^{2}$ Nos termos marxianos: os produtos se tornam mercadoria pelo comércio, diferindo da produção subsumida ao capital, onde a própria produção já é necessariamente produção de mercadorias.
} 
contraste com a sociedade feudal é, também, particularmente nítido. A "economia" em seu sentido formal não articula aquela sociedade. As aldeias tendiam à autossuficiência e, essencialmente, não obedeciam aos padrões impostos pelo mercado. $\mathrm{O}$ que as articulava eram relações de poder exercidas diretamente pela camada dominante, as quais eram percebidas originalmente como relações pessoais e sagradas. Neste caso, os "mecanismos de mercado", como tentarei demonstrar, operavam em setores claramente delimitados e não fundamentais da sociedade feudal.

Logo, uma dimensão crucial na análise da formação do capitalismo envolve identificar os mecanismos indutores e as vias que levaram o capital mercantil a romper dois constrangimentos fundamentais. O primeiro grupo deles envolve os bloqueios à penetração na "produção" que o impediam de converter a força de trabalho em mercadoria, fenômenos exaustivamente analisados por praticamente todas as correntes do marxismo. O segundo conjunto, geralmente estudado por tradições teóricas distintas do materialismo histórico, envolve os constrangimentos que confinavam os grandes mercadores a um grupo específico de status, geralmente pouco prestigioso. Ficavam, portanto, duplamente presos. Do ponto de vista da divisão do trabalho, estavam confinados à função de comerciantes, sendo geralmente impedidos de comprar terras e de organizar diretamente a produção ${ }^{3}$. Além disto, como não podiam se mesclar livremente a outros grupos de status, por mais que enriquecessem, não podiam ocupar os níveis superiores da hierarquia de prestígio ${ }^{4}$. A ênfase aqui recairá no primeiro conjunto, embora, quando oportuno e necessário, serão feitas alusões às interações entre estas duas formas mais gerais de constrangimento.

\section{A polêmica sobre as duas vias para o capitalismo}

Como já foi apontado, partirei da capciosa polêmica sobre as "duas vias" - ou, os dois "modos", como a maior parte das traduções de O Capital preferem grafar -

\footnotetext{
${ }^{3}$ Um dos bloqueios mais importantes nas sociedades arcaicas ao reforço do poder dos mercadores era a proibição das atividades lucrativas com os alimentos que operava de forma similar aos tabus que regiam o sexo e a autoridade (seja do chefe ou dos sacerdotes). (POLANYI, 2012, p. 110-1). As trocas podiam ocorrer - e muitas vezes, atingiam volumes consideráveis - entre aldeias ou entre sociedades, mas que mantinham uma relação de complementaridade (algumas se especializavam na oferta de peixe, outras de peles etc.), que preservava um certo grau de divisão do trabalho entre as sociedades, mas que afetava pouco as suas interações internas. Não há, portanto, um mecanismo de trocas de tipo capitalista, que além de sua abrangência tendencialmente universal (e, em especial, sua capacidade de mercantilizar a terra e a força de trabalho), gera uma intensa concorrência de ofertantes de mercadorias similares.

${ }^{4}$ De forma indireta, isto limitava muito a influência da riqueza na estratificação social. De um modo geral, o componente material da riqueza - tanto a massa de bens quanto os objetos que simbolizam a riqueza - sempre tiveram uma importância secundária nas hierarquias da vida social. É a sociedade produtora de mercadorias que irá transformar significativamente esta relação.
} 
da transição do feudalismo ao capitalismo que ocuparam uma posição de destaque na clássica controvérsia entre Dobb e Sweezy ${ }^{5}$. A via número I seria representada pelos pequenos e médios produtores que se convertem em comerciantes $e$ capitalistas (em oposição às zonas dominadas pelos camponeses autônomos e às regulações corporativas na cidade, que limitavam a produção para o "mercado" baseada no assalariamento), enquanto a via número II envolveria o movimento oposto, isto é, os grandes mercadores - plenamente integrados aos círculos superiores da sociedade feudal - que, com sua riqueza, passam a se apoderar da produção no campo e nas cidades.

O desentendimento básico derivou da célebre resenha de Sweezy sobre Studies in the development of Capitalism (DOBB, 1950), a qual, como se sabe, por provocar uma réplica de Dobb, inaugurou o debate sobre a transição do feudalismo ao capitalismo. Sweezy abordou o problema das duas vias à luz de suas preocupações pessoais, isto é, tendo em vista os mecanismos de centralização e concentração de capitais que levaram à crise de 1929 e seus efeitos potenciais sobre o capitalismo do imediato pós Segunda Guerra Mundial. Dobb, por sua vez, ao redigir o capítulo 2 dos Studies..., tinha um problema completamente distinto em vista: a peculiaridade e as forças sociais que desencadearam a Revolução Inglesa de 1640. Por isso, ele vê como revolucionária a via fundada no (lento) processo de expansão das propriedades por parte dos artesãos enriquecidos e dos yeoman, que se associaram de forma mais intensa com a articulação entre o putting out system e as redes manufatureiras. Na revolução, pelo menos no modo como Dobb a concebe, estas forças tinham como antagonistas principais a nobreza rentista e os grandes mercadores e, por conta disto, forneceram a base da New Model Army de Cromwell. Além disto, para Dobb, somente os camponeses mais prósperos - que, sintomaticamente, ele por vezes se refere como "Kulaks" - e os artesãos agiam como capitalistas, pois recorriam à mão de obra assalariada e eram forçados a ampliar e aprimorar as suas unidades produtivas (assim como eram

\footnotetext{
${ }^{5}$ O termo "duas vias" ao invés de "dois modos" se popularizou aqui provavelmente pelo fato da primeira tradução para o Português (da editora portuguesa Dom Quixote) dos artigos que compõe o debate clássico ter optado pelo primeiro termo. A tradução brasileira (Paz e Terra) manteve essa mesma grafia. Em O Capital, em uma das traduções para o português, a passagem é a seguinte: "A transição a partir do modo de produção feudal se efetua duplamente. $\mathrm{O}$ produtor se torna comerciante e capitalista, em antítese à economia natural agrícola e ao artesanato preso à corporação da indústria urbana e medieval. Esse é o caminho realmente revolucionador. Ou, então, o comerciante se apodera diretamente da produção. Por mais que esta última via atue historicamente como transição - como, por exemplo, o clothier inglês do século XVII, que submete os tecelões que, no entanto, são autônomos, vendendo-lhes sua lã e comprando-lhes o tecido - , tanto menos ela, em si e por si, leva ao revolucionamento do antigo modo de produção, pois, antes, o conserva e o mantém como pressuposto" (MARX, 1988, p. 239). A tradução para o inglês feita por David Fernbach é bastante similar: "The transition from the feudal mode of production takes place in two different ways. The producer may become a merchant and capitalist, in contrast to the agricultural natural economy and the guild-bound handicraft of medieval urban industry. This is the really revolutionary way. Alternatively, however, the merchant may take direct control of production himself. But however frequently this occurs as a historical transition - for example the English clothier of the seventeenth century, who brought weavers who were formerly independent under his control, selling them their wool and buying up their cloth - it cannot bring about the overthrow of the old mode of production by itself, but rather preserves and retains it as its own precondition" (MARX, 1991, p. 452).
} 
"pressionados" a enfrentar as formas feudais de controle fundiário e as regulações corporativas na cidade). O movimento dos grandes mercadores era distinto: eles se associaram às guildas para dominar o artesanato urbano e orientá-lo para o comércio mundial, bem como adquiriram propriedades no campo para explorar o mercado internacional dos têxteis de lã ${ }^{6}$. Logo, mesmo incorporando a produção baseada no trabalho livre, estas forças sociais tentavam preservar a subordinação da produção à lógica do capital mercantil e, portanto, no limite, eram conservadoras.

A tônica da interpretação de Dobb, portanto, é a contraposição entre forças sociais distintas. Resvalando no mito do burguês herói, ao movimento dos pequenos e médios burgueses que, na medida em que cresciam, revoltaram-se contra a exploração feudal, extirpando a aristocracia do controle do Estado e eliminando a servidão, Dobb contrapõe o oportunismo dos grandes mercadores, que queriam proteger seus círculos sociais e, essencialmente, preservar as disparidades de preço. Eles invadiram a produção por causa disto e, na hora da revolução (política), ao apoiarem as prerrogativas feudais, mostraram a sua feição conservadora.

Sweezy, por sua vez, faz uma interpretação sobre a passagem de Marx tendo como referência principal a dimensão mais abstrata da lógica da concorrência dos capitais, deixando em segundo plano a questão da estratificação social e da luta de classes. No seu entender, a diferença entre as vias repousa essencialmente no volume e na velocidade das transformações. A via tomada pelos pequenos produtores e artesãos, que ampliam gradualmente suas propriedades, é muito mais lenta e, sobretudo, dispersa: as articulações entre as transformações fundiárias, o putting out, as manufaturas e as poucas fábricas são efêmeras. Neste passo de tartaruga, dificilmente o capitalismo poderia se consolidar (no máximo, esta via produz o famigerado "sistema produtor de mercadorias" que ele cunhou durante a polêmica com Dobb). O termo revolucionário, portanto, para ele, tem outro significado. A via é revolucionária porque o capital mercantil predominantemente nas mãos dos grandes mercadores, que concentravam a riquez̧a e as conexões sociais - possibilitou a unificação das diversas fases da produção em um mesmo comando "capitalista". Logo, exatamente por se situar nos pontos nodais dos sistemas de comércio, os grandes mercadores podiam dominar - a partir dos canais de distribuição e acabamento - toda a rede de produção que emanava da agricultura comercial e das manufaturas ${ }^{7}$. E, além do controle sobre as novas

\footnotetext{
${ }^{6} \mathrm{O}$ mercado de tecidos de algodão, considerado mais vulgar, era operado predominantemente por pequenos e médios produtores.

${ }^{7}$ Uma imagem, embora imprecisa, porque baseada na confusão entre História da formação do capitalismo e gênese de elementos, favorece o entendimento do argumento de Sweezy: o mercador compra ou domina o processo de "traz para a frente", isto é, dos canais de distribuição (onde ele se situa) para a produção. O movimento oposto - a via do pequeno produtor - aparentemente segue o processo capitalista "regular", isto é, onde as mercadorias já são geradas "na produção" - por intermédio da máquina-ferramenta - e realizadas no mercado. Porém, pelo volume e magnitude, é a via tomada pelos grandes mercadores que, ao subordinar as redes formadas pelos pequenos e médios produtores, possibilita a eclosão da Revolução Industrial.
} 
formas de produção em marcha, essa concentração de recursos possibilitava a criação de empreendimentos capitalistas mais "amadurecidos", tais como a mineração, a metalurgia, a produção em grande escala de bebidas fermentadas (cerveja e vinho), as minas de sal, fábricas de sabão e o refino do açúcar (exemplos todos compreendidos entre 1540 e 1640, que ele retira diretamente de NEF (1940). Logo, a via é revolucionária no sentido de, mediante a concentração de riquezas e a articulação dos processos produtivos, abrir o caminho para a primeira Revolução Industrial. Tanto faz a origem social destes "capitalistas": o que importa é que, independentemente de suas motivações, eles implantaram empreendimentos "genuinamente" capitalistas.

Antes de prosseguir, é importante marcar como esta forma de abordar o problema gerou confusões suplementares. Uma delas diz respeito ao papel do Putting out system $^{8}$. Sweezy o enxerga basicamente como uma etapa intermediária, mas que acaba sendo ultrapassada pela via que ele qualifica como revolucionária, exatamente pela expansão da escala de produção, possibilitada pela riqueza dos mercadores (e pela indução do Estado, aspecto enfatizado por Lefebvre na sua intervenção no debate). Dobb, por sua vez, em consonância com os seus próprios critérios, tende a qualificar o putting out como parte da via revolucionária. O problema é que este sistema fazia parte dos tentáculos do capital mercantil. E, embora Sweezy não faça menção a isto, ele pode ser entendido como uma etapa intermediária em um sentido bastante preciso: ele dependia de pelo menos dois elementos da sociedade feudal $e$ dos circuitos do capital mercantil. Sua base era a possibilidade de a família camponesa dedicar pelo menos um membro ou parte do

\footnotetext{
8 Este termo, muito popular nos círculos marxistas, também encerra alguma polêmica. Dobb, com alguma reticência - e provavelmente influenciado por Engels -, tende a utilizá-lo ora como sinônimo de Verlagssystem, ora como o equivalente ao Kaufsystem (o que é mais preciso). O Verlagssystem envolve unidades de produção relativamente grandes, com um nível de divisão do trabalho significativo e dominado pelo "marchantfabricant" / mercador empreendedor. Não é, portanto, similar à produção domiciliar, embora geralmente recorra a ela de forma sistemática, para realizar algumas etapas da produção. Já o Kaufsystem envolve a produção dispersa entre as diversas famílias camponesas, sob articulação e domínio do capital mercantil (STEVENS-COX, 1999, p. 54-6). Estas duas formas de produção, contundo, tendem a coexistir e, na realidade a se interpenetrar, a ponto de formar um conjunto coerente e articulado de relações, que também envolvem o que se convencionou chamar de manufaturas. Fernand Braudel - que opta conscientemente por não distinguir as duas formas (para evidenciar a sua articulação) - destaca a sua importância e seu sentido básico: “As redes do sistema são as primeiras características inegáveis de um capitalismo mercantil cujo intuito é dominar e não transformar a produção artesanal. Na verdade, o que mais lhe interessa é a venda. Concebido desse modo, o Verlagssystem pode aplicar-se a qualquer atividade produtiva, desde que o mercador obtenha uma vantagem em se lhe sujeitar. Tudo favorece essa proliferação: o desenvolvimento geral da técnica, a aceleração dos transportes, o aumento do capital acumulado, manipulado por mãos hábeis e, por fim, o surto das minas alemãs, a partir de 1470” (BRAUDEL, 1996, p. 280). Isso altera os termos da discussão: a manufatura, na realidade, sempre esteve envolvida e, de certo modo, subjugada pelas redes do Verlagssystem. "Poder-se-ia pensar que a manufatura se multiplica, assim, de dentro para fora, à medida que vai crescendo. Mas é antes o inverso que é verdadeiro, se pensarmos na própria gênese da manufatura. Na cidade ela é muitas vezes o término de redes de trabalho a domicílio, o local onde, em última instância, se completa o processo de produção" (BRAUDEL, 1996, p. 288-9). O fato é que, até a generalização da produção mecanizada, o desenvolvimento das manufaturas irá estabelecer uma tensa relação com as Guildas: precisa aliciar seus membros para o acabamento, ao mesmo tempo que gera uma concorrência - produtos muito mais grosseiros, mas extremamente baratos - com a produção nas oficinas.
} 
seu tempo para produzir ou processar as encomendas do contratante 9 . O segundo elemento está na cidade: somente os artesãos eram capazes de completar o produto (acabamento) e, portanto, tinham de ser aliciados pelos mercadores para fazê-lo. Assim, tanto as manufaturas quanto o putting out demandavam artesãos que, por sua vez, só podiam obter suas habilidades específicas por meio do aprendizado típico das corporações de ofício.

Isto representou, portanto, um ponto cego do debate clássico, que ficou girando em torno da "correta" compreensão de passagens retiradas de O Capital, assim como na especulação sobre a diferenciação de um Putting Out inglês organizado "de baixo para cima" ou a partir dos grandes mercadores. O fato é que o capital mercantil efetivamente toca na "produção" - de forma oblíqua, é claro - ao se associar às famílias camponesas pelo Putting out e aos trabalhadores "livres" reunidos nas manufaturas. A posição das guildas era francamente hostil a estes desdobramentos, pois eram instituições destinadas a perpetuar saberes específicos, guiadas pela noção de preço justo e códigos de conduta estranhos ao capitalismo. Mas os aprendizes (e artesãos sem ofícios) eram imprescindíveis para o capital mercantil. Sem eles o Putting out e as manufaturas não poderiam se materializar. Esta tensão operou até a invenção e a generalização da máquina-ferramenta que, em meio à carga do interesse mercantil contra algumas restrições das guildas à expansão do comércio, despedaçou de vez a antiga resistência corporações de ofício e redefiniu o sentido do artesanato.

Aqui tocamos novamente no centro do problema. Como caracterizar o papel do capital comercial? É uma força transformadora ou uma barreira ao modo de produção especificamente capitalista? Diversos autores, cada um a seu modo, afirmam que se trata simultaneamente das duas coisas. Ora se enfatiza o seu papel como uma força que operou dominantemente no sentido de dissolver algumas características da sociedade feudal. Neste caso, portanto, as transformações em um sentido positivo - i.é. a construção e a articulação dos elementos do modo de produção capitalista - devem ser buscadas fora do seu âmbito e, essencialmente, respondendo a outras determinações. Por outro lado, além deste papel desintegrador, é bastante comum destacar também o seu papel ativo na transição: ele teria não somente acelerado a destruição de parte dos fundamentos da sociedade feudal, como teria também favorecido a emergência e a concatenação de elementos capitalistas fundamentais. Nos dois casos, a despeito de suas diferenças evidentes, há uma noção comum de limite. O problema é, exatamente, definir quais são esses limites e como eles operam.

\footnotetext{
${ }^{9}$ Como atividade perene as condições são diferentes: é necessária a elevação da produtividade no campo e/ou a redução da exploração sobre os camponeses. Na outra ponta, é preciso encontrar um mercado para esta produção. Enquanto atividades ocasionais, as redes de putting out só se generalizavam nos períodos de entressafra, onde aumentava a disponibilidade de mão de obra para atividades não diretamente ligadas à agricultura (fato que aumentava a predisposição dos camponeses a buscar atividades não-agrícolas).
} 
A forma mais usual de tratar esta questão envolve predominantemente a exegese dos textos marxianos (e, em menor grau, de alguns dos intérpretes canonizados pelos aparelhos burocráticos do finado "socialismo real") e a busca de uma solução no plano da teoria. Esse modo de abordar o problema parece já ter atingido seus limites. Além disto, na esmagadora maioria dos casos, este tipo de abordagem se fundamenta em um pressuposto - geralmente oculto - bastante discutível: que o modo de produção capitalista foi o produto inevitável da crise do feudalismo. E isso, a despeito de constantes referências às revoluções, descompassos, contradições etc., situa o problema dentro de uma noção de continuidade, que deve ser vigorosa e radicalmente combatida. A discussão sobre as duas vias, ao ser formulada nos termos acima propostos ${ }^{10}$, ilustra isto de forma eloquente. É fundamental, portanto, tentar mudar o terreno, deslocando a reflexão para os domínios da História, ressaltando o caráter singular da transição e, essencialmente, destacando que este fenômeno só pode ser reconstituído - seja no plano narrativo ou no "teórico" - mediante a articulação do conjunto das esferas da existência social. E, é importante insistir, uma das formas de fazê-lo envolve buscar o nexo historicamente estabelecido entre as transformações no plano da divisão social do trabalho, a luta de classes e a transformação no sistema de prestígio social (onde a questão das identidades sociais fica mais explícita.)

\section{As cidades e a transição do feudalismo ao capitalismo}

Isto nos leva a revisitar brevemente outro tema célebre do debate marxista sobre a formação do capitalismo: o papel das cidades. Neste caso, partiremos também do modo como essa questão aparece no debate clássico sobre a transição. A crítica de Sweezy à Dobb, a princípio pelo menos, teria aberto a possibilidade de reabilitar a explicação clássica, que remontaria aos inícios de pensamento liberal. E, supostamente, teria sido desenvolvida por Pirenne (e por Weber): a peculiaridade do Ocidente derivou, em grande parte, da especificidade de sua cidade. Isto é, a sua capacidade de se constituir como núcleos organizacionais autônomos ${ }^{11}$, aptas a operar, portanto, como microcosmos capitalistas. Sendo capazes de não somente dissolver o feudalismo, mas, também, induzir a formação do capitalismo, ao possibilitar a articulação entre os mercados internacionais e os locais e, com isto,

\footnotetext{
${ }^{10}$ Essa qualificação é importante. Dobb tentou se desvencilhar da noção de inevitabilidade da transição, ao tentar pensar a crise do feudalismo como um produto das suas contradições internas, mas que se materializa pela luta de classes. O que ele estava reivindicando era, exatamente, fugir dos modelos abstratos, em direção à História. Sweezy, por sua vez, ficou mais distante dessa tarefa. O modo como ele inicia a sua abordagem ao livro de Dobb é elucidativo: "Vivemos no período de transição do capitalismo para o socialismo, fato que empresta particular interesse ao estudo das transições anteriores de um sistema social para outro".

${ }^{11}$ A cidade antiga não era autônoma no sentido das cidades da Idade Média, pois o seu caráter político dependia dos latifúndios rurais que garantiam o sustento - e indiretamente o poder - dos mais notáveis cidadãos. Já a cidade medieval era um núcleo administrativo e uma unidade econômica com grande potencial de autarquia.
} 
impulsionar o artesanato urbano $e$ submeter o campo ao dinamismo de uma economia mercantil centrada nos núcleos urbanos.

Curiosamente, já nos Studies... Dobb já havia feito uma crítica devastadora a esse tipo de raciocínio. $\mathrm{O}$ argumento, bastante contundente, parte da seguinte constatação:

Mas, embora tais comunidades urbanas, na medida em que eram centros independentes de comércio e de acordos contratuais e, em certo sentido, eram corpos estranhos [alien bodies] cujo crescimento favorecia a desintegração da ordem feudal, seria errôneo encará-las, nesse estágio, como microcosmos do capitalismo. Fazế-lo seria antecipar desenvolvimentos que pertencem a um estágio posterior. Nem podemos encarar a sua existência como a operar em todas as circunstâncias como solventes necessários das relações feudais. É verdade que o elemento mercantil que estas comunidades nutriram eram os primeiros germes do capital mercantil e usurário que seria posteriormente empregado em grande escala. Mas outros instrumentos de acumulação, além de uma mera tendência ao estilo bola de neve tiverem de intervir antes que este capital se tornasse tão dominante e ubíquo como viria a ser nos séculos posteriores (DOBB, 1950, p. 71).

E, o que é mais importante, nas páginas seguintes, Dobb explora a bibliografia clássica sobre as origens das cidades no Ocidente, mas tendo como referência uma preocupação fundamental: o fato de as cidades - que, como ele mesmo mostra, podem ser divididas em diversos tipos - lutarem pela autonomia (frente a um príncipe que as queria subjugar) tem que ser inserido em um movimento muito mais geral: a tensão entre os nobres, e entre os nobres e os camponeses.

Logo, o papel das cidades na transição ao capitalismo deve ser visto, essencialmente, como um produto da crise geral do feudalismo, mediada pela luta de classes. Mas, em síntese, podemos afirmar que as cidades não podem ser concebidas como microcosmos capitalistas por pelo menos dois motivos: i) o artesanato e a produção de "mercadorias" realizadas em seu interior era fundada nos códigos de conduta das corporações, cuja orientação não era a acumulação. A produção para o "mercado" era vista, essencialmente, como um meio para preservar os ofícios, este sim concebidos como um fim em si. A lógica da produção mercantil capitalista teve, para poder andar sobre seus próprios pés, de destruir as relações sociais tradicionais no campo e as regulações das corporações; ii) as cidades - e aqui temos de nos afastar um pouco da interpretação de Dobb, que aponta na direção certa, mas com um argumento um pouco impreciso ${ }^{12}$ - eram também

\footnotetext{
12 Dobb afirma que, em última análise, as cidades estavam subordinadas à autoridade feudal, de forma similar aos aldeões e aos pequenos proprietários alodiais no campo (1950, p. 71-2). Há dois momentos: durante a grande expansão a partir do século XI, as cidades tornaram-se uma forma específica de autoridade feudal, uma espécie de
} 
baseadas na noção de privilégio e em códigos de conduta medievais. Não representavam, portanto, corpos totalmente estranhos à sociedade feudal. Se agiram como "solventes" do feudalismo, é porque sofreram também transformações, que refletem mecanismos mais profundos e com temporalidades variadas.

Esse ponto nem sempre mereceu a atenção devida entre os marxistas. Os burgueses - na sua acepção original, i.é. habitantes do burgo ${ }^{13}$ - eram bastante zelosos com os seus privilégios: eram os únicos com direito de "cidadania", a qual valia apenas para o seu burgo e representava o principal critério de diferenciação social. Logo, como atesta o próprio Pirenne, a origem e o papel inicial da burguesia nada tiveram de revolucionário:

É importante salientar que esta ordem social é aceita pela burguesia. Sua demanda e aquilo que poderíamos denominar o seu programa político não buscava de nenhum modo destruí-la; pois ela admite sem questionar os privilégios e a autoridade dos príncipes, do clero e da nobreza. Esta classe meramente desejava obter, simplesmente por ser necessária à sua existência, não a subversão da ordem, mas simples concessões. E concessões limitadas às suas próprias necessidades. Ela não tinha nenhum interesse nas necessidades da população rural de que emergiu. Em suma, ela pedia somente à sociedade que lhes concedesse um lugar compatível com o estilo de vida que estava levando. Não era revolucionária e, se recorria à violência, não era por ódio contra o regime, mas simplesmente para forçá-lo a ceder (PIRENNE, 1946, p. $169-70)^{14}$.

A sua luta pela constituição de uma nova unidade político administrativa (a cidade medieval) era travada sem questionar essencialmente os marcos da sociedade medieval:

Como o clero e como a nobreza, a burguesia é uma ordem privilegiada. Ela forma um grupo legal distinto e o direito especial de que goza a isola da massa do povo rural, que continua a formar a imensa maioria da população. Realmente (...) ela era obrigada a manter intacto o seu

\footnotetext{
"senhorio coletivo", que se baseava em privilégios peculiares (ANDERSON, 1974, p. 20-1; MERRINGTON, 1975). Em um segundo momento, já em meio à crise do feudalismo (e é neste período que Dobb concentra a sua análise), quando a centralização de poder em torno da Coroa se acelerou, como veremos, o Rei passou a ameaçar a autonomia das cidades, que acabaram transformando a sua forma de organização e a forma da sua integração com o campo.

${ }^{13} \mathrm{O}$ significado deste termo é discutido no apêndice.

${ }^{14}$ As traduções em inglês costumam substituir o termo bourgeoisie por middle classes, um procedimento usual na língua inglesa, mas inaceitável nas outras linguagens.
} 
status excepcional e reservar apenas a si os benefícios dele decorrentes. A liberdade, tal como a classe média a concebia, era um monopólio. (PIRENNE, 1946, p. 213-4).

Esta não é uma passagem isolada. De um modo geral, a obra de Pirenne sempre destacou o caráter privilegiado dos burgueses e ele afirmou explicitamente que as transformações derivadas de sua existência (o fim do feudalismo, o liberalismo etc.) não foram conscientes ${ }^{15}$.

O segundo ponto de semelhança com a senhoria rural é o exercício direto do poder político - isto é, a violência privada, exercida pelo patriciado por meio da sua milícia - para a defesa e, também, para garantir o controle sobre as camadas mais baixas da sociedade. Mas, tal como no feudo, o poder político exercido no campo circundante era repleto de condicionalidades que, de um modo geral, de forma involuntária ${ }^{16}$, preservavam a posição do produtor rural. Mesmo quando as relações cidade-campo (sempre levando em conta as cercanias do burgo) que envolviam alimentos eram estabelecidas pelo "mercado", em nome do preço justo, os intermediários eram proibidos, fato que engendrava, na realidade, um comércio administrado por instâncias estranhas ao mercado e que, portanto, não se assemelha ao capitalista. Era este tipo de arranjo que garantia a preservação da cidade como uma forma particular de autoridade feudal.

Mas, para além da sua relação com o mercado local, a cidade também operava como um nódulo do capital mercantil. E aqui é um momento oportuno para

\footnotetext{
${ }^{15}$ Curiosamente, este juízo acertado decorre do principal problema de sua interpretação: é o ressurgimento do comércio de longa distância e seu impacto nas práticas sociais (uma nova concepção de riqueza) e na própria estrutura da sociedade (a valorização mercantil da terra, por exemplo, que "liberta" as populações rurais) é que gera as determinações fundamentais na dissolução da ordem feudal. Os mercadores e o patriciado urbano são meros instrumentos operando ao sabor dessas forças impessoais, lutando para tentar se integrar em uma ordem social sofrendo transformações profundas, porém muito lentas. Após discutir como as transformações nas práticas sociais derivadas de uma sociedade crescentemente imersa no mercado produziam as tensões entre a "burguesia" e as forças sociais mais características do feudalismo (o episcopado e demais autoridades da Igreja Católica, os senhores rurais, a posição ambivalente com o Rei etc.), Pirenne conclui o livro com um parágrafo magistral: "Simultaneamente místicos e religiosos, os burgueses da Idade Média estavam singularmente bem preparados para o papel que iriam desempenhar nos dois grandes movimentos das idéias: a Renascença, filha da mente laica, e a Reforma, para onde o misticismo religioso estava apontando" (1946, p. 234).

16 A ideia não era, evidentemente, proteger de forma altruísta o camponês, mas preservar o monopólio das atividades urbanas e seus privilégios. Pirenne já tinha destacado esse ponto "Ao ardor do patriotismo local corresponde o seu exclusivismo. Pelo próprio fato de que cada cidade constitui um Estado, as cidades se veem umas às outras apenas como rivais ou inimigas. Não podem ultrapassar a esfera dos seus próprios interesses. São autocentradas e o sentimento que compartilham com suas vizinhas lembra, embora de forma mais estreita, o nacionalismo dos nossos dias. O espírito cívico que as anima é singularmente egoísta. Reserva para si de forma invejosa as liberdades de que goza dentro das suas muralhas. Os camponeses que viviam no entorno das cidades não lhes pareciam como compatriotas. O seu único pensamento era explorá-los lucrativamente. Busca com toda a sua força os impedirem de se integrarem ao sistema industrial de que possuem o monopólio. A tarefa de garantir o abastecimento das cidades foi imposta aos camponeses, que sempre eram submetidos a um protetorado tirânico, quando tinham poder para tal, como, na Toscana onde, por exemplo, Florença submeteu ao seu jugo todo o campo nos seus arredores" (1946, p. 210-11).
} 
incluir na discussão o que Karl Polanyi - e, de certo modo, Henri Pirenne - tem de melhor. A despeito da coincidência em um mesmo espaço, a organização da vida urbana impedia a articulação entre os mercados locais e o comércio de longa distância. Como já foi dito, as regulamentações locais bloqueavam, no comércio local (especialmente se envolvesse alimentos ou fatores de produção considerados essenciais) qualquer forma de comércio por atacado. A posição privilegiada do burguês, portanto, dependia da preservação dos mercados locais - que, se existentes, estavam incrustrados nas estruturas do cotidiano, e não tinham forç para transformá-las - e da sua desarticulação com o mercado de longa distância, cujo trato básico envolvia bens de consumo conspícuo (inclusive nos gêneros alimentícios: especiarias, peixe salgado e o vinho de qualidade), gerando um tipo de mercado que não pode ser confundido com o capitalista ${ }^{17}$, que envolve necessariamente a terra, a força de trabalho e demais fatores de produção (isto é, as mercadorias "fictícias", na curiosa visão de Polanyi).

Em uma passagem muito elucidativa, Polanyi expõe com elegância a peculiaridade da cidade feudal:

O resultado mais significativo dos mercados - o nascimento de cidades e a civilização urbana - foi, de fato, o produto de um desenvolvimento paradoxal. As cidades, as crias dos mercados, não eram apenas as suas protetoras, mas também um meio de impedi-los de se expandirem pelo campo e, assim, incrustarem-se na organização econômica corrente da sociedade. Os dois significados da palavra 'conter' talvez expressem melhor essa dupla função das cidades em relação aos mercados, que elas tanto envolviam como impediam de se desenvolver (POLANYI, 2000, p. 82-3).

Logo, exatamente por serem associações autônomas de burgueses, as cidades bloqueavam a generalização dos mercados, em especial, dos mercados típicos do capitalismo, isto é, formadores de preços, onde mercadorias similares, mas provenientes de fontes distintas são intercambiadas em constante competição. A cidade feudal era, portanto, um dique que continha, mas também represava, mercados de tipos diferentes.

Além disto é necessário frisar um aspecto importante: o modo de produção capitalista promoveu uma reformulação radical do comércio e do mercado que, se

\footnotetext{
17 John Merrington também destaca esse ponto: “O mercado era um troféu reservado para poucos, e sua 'conquista' representava o reforço do monopólio da produção e do comércio contra o campo, bem como contra os avanços das cidades rivais. Enquanto o mercado dependeu das disparidades de preço entre esferas distintas de produção nas quais os produtores não estavam separados dos meios de produção e subsistência, o comércio apenas existia nos interstícios do sistema, monopolizando o suprimento de uma limitada linha de mercadorias, sendo dependente da indulgência política: era mais "uma estrutura de tributos do que uma estrutura de comércio"' (1975, p. 80-1).
} 
não for devidamente levada em conta, deforma a visão das sociedades precedentes e, por conta deste anacronismo, oculta as contradições e as descontinuidades que marcaram a formação do capitalismo. É a equalização - geralmente inconsciente entre comércio e mercado, e entre mercado e sociedade de mercado que tende a aprisionar o pensamento liberal em tautologias que assumem como a explicação exatamente o que deveria ser explicado. De um modo geral, nas sociedades précapitalistas as relações comerciais eram muito variadas e, essencialmente, todas elas estavam incrustradas em outras relações sociais, fato que trazia pelo menos duas implicações: os diversos tipos de mercado não eram diretamente comunicáveis e, essencialmente, não possuíam um dinamismo próprio.

No caso específico do feudalismo é vital caracterizar os tipos de mercado e, essencialmente, o modo como eles se vinculam às estruturas agrárias e às forças sociais. Os mercados locais ficavam circunscritos aos entroncamentos entre as aldeias e nas cercanias das cidades. Mas o ponto decisivo é outro. Mesmo quando volumosos, o seu papel na reprodução global da sociedade era marginal e, o que é mais importante, eles eram incapazes de alterar a sua orientação. A vida material da maioria das aldeias era regida por formas de produção predominantemente coletivas (compartilhamento do arado e dos animais de tração, trabalho conjunto no manso servil etc. $)^{18}$, fundadas predominantemente no replantio e, portanto, independentes do mercado de tipo capitalista. Logo, somente a parcela que ultrapassava a subsistência dos produtores - e que não era apropriada pela nobreza - podia alimentar os mercados locais. O consumo da nobreza, por sua vez, dependia predominantemente de sua capacidade de exploração sobre a economia agrária. Portanto, além de operaram de forma muito distinta, o mercado local e o comércio de longa distância são inversamente proporcionais: para expandir o seu acesso ao consumo suntuoso, a nobreza tendia a elevar os seus níveis de exploração, fato que, caso não ocorra nenhum crescimento extensivo (ou a elevação do produtividade nas aldeias), redu o volume dos mercados locais e, no limite, pode até mesmo comprometer a capacidade de subsistência dos camponeses ${ }^{19}$. Portanto, a

\footnotetext{
18 As aldeias que surgiram na orla do Mediterrâneo na região do antigo Império Romano eram mais próximas de uma aglomeração de pequenos produtores independentes baseados em uma economia mercantil simples. Nesta zona os pequenos produtores alodiais ficaram presos à terra (que deixou de ser considerada uma propriedade) enquanto os antigos escravos se tornaram servos, presos agora a um lote de terra que pertencera ao latifúndio romano. Mesmo assim, o replantio era a regra, e a influência do mercado sobre a vida social era reduzida.

19 Por volta do ano 1000 tem início uma fase de expansão populacional e do comércio que durou quase três séculos, entrecortada por diversas transformações importantes na sociedade feudal. Tanto o mercado local quanto o de longa distância cresceram conjuntamente, fato que fortaleceu a ilusão de que estes dois mercados são compatíveis e capazes de estabelecer sinergias (embora predomine a visão de que foi a reativação do comércio de longa distância que dinamizou os mercados locais e, no longo prazo, dissolveu o feudalismo). Como dito, estes dois mercados não se comunicavam pelas relações "econômicas" e, no limite, eram inversamente proporcionais. Quando este problema ressurgiu na segunda fase do debate - o "debate Brenner" - ele foi varrido para debaixo do tapete, por conta de um artifício usado por Robert Brenner: uma leitura deformada da dita "interpretação demográfica", que ganhou uma aceitação quase automática por parte dos marxistas. O que os interpretes mal qualificados como "demográficos" fazem é destacar o óbvio: na sociedade feudal, os mercados tem uma influência muito exígua sobre os rumos da sociedade, e seu crescimento e expansão devem ser explicados por transformações
} 
articulação entre estes dois mercados, além de indireta, envolve classes diferentes e se estabelece, essencialmente, pelo ação dos mecanismos de exploração típicos do feudalismo.

Logo, a explicação do mecanismo que rompeu estes diques e possibilitou a articulação dos mercados não pode ser baseada no movimento do próprio comércio. A formação dos Estados - e sua "política" dita mercantilista - é uma das determinações fundamentais. Karl Polanyi afirma isto de forma veemente:

$\mathrm{Na}$ Europa Ocidental o comércio interno foi criado, na verdade, por intervenção do Estado. Até a Época da Revolução Comercial, o que pode nos parecer como comércio nacional não era nacional, e sim municipal. Os hanseáticos não eram mercadores germânicos; eles eram uma corporação de oligarcas comerciais, sediados em diversas cidades do Mar do Norte e do Báltico. Longe de 'nacionalizarem' a vida econômica germânica, a Hansa deliberadamente isolava o interior do comércio. O comércio da Antuérpia ou Hamburgo, Veneza ou Lyon não era, de forma alguma, holandês ou germânico, italiano ou francês. Londres não era exceção: ela era tão pouco 'inglesa' como Luebeck era 'germânica'. O mapa comercial da Europa nesse período mostraria corretamente apenas cidades, deixando em branco o campo - este parecia não existir no que concerne ao comércio organizado. As assim chamadas nações eram apenas unidades políticas, na verdade bastante frouxas, e que consistiam, economicamente, de inúmeros ambientes domésticos autossuficientes, maiores ou menores, e insignificantes mercados locais nas aldeias. O comércio limitava-se a distritos organizados que o praticavam localmente, como comércio de vizinhança, ou como comércio de longa distância - os dois eram

em outras instâncias sociais: isto é, no modo como, na vida cotidiana, se estabelecem os nexos que produzem os gêneros vitais (com especial ênfase na agricultura - que grãos, como eles são plantados e colhidos - e em sua relação com a "pecuária", bem como no impacto que esta articulação exerce na dieta, na organização da vida familiar e, essencialmente, na proporção homens/mulheres) e como eles são redistribuídos. Deixando as peculiaridades das diversas correntes em segundo plano, o que tais intérpretes sustentam - corretamente - é que o conjunto de transformações generalizadas entre 950 e 1050 (a difusão do sistema de três campos, com a progressiva introdução de leguminosas na zona de alqueive, a sinergia entre a produção de cereais e a "pecuária" (predominantemente situada nas terras marginais), a intensificação do uso do ferro e da proteína na dieta, etc.) geraram uma tendência ao aumento populacional que, ao multiplicar as aldeias (processo que se combinou com a elevação da produtividade: mais tração animal, aprimoramento da rotação de culturas, etc.) e o número de camponeses com tempo disponível para atividades não diretamente agrícolas, desenvolveu os mercados locais, assim como a produção domiciliar e o Verglagssystem (que estabelecia algum contato com os mercados de longa distância). Simultaneamente, mesmo com o aumento populacional da nobreza, foi possível elevar as prestações feudais sem comprometer os mercados locais e a producão camponesa. Logo, os dois mercados crescem conjuntamente pois, além da melhoria da produtividade (modesta, mas efetiva), era possível crescer extensivamente. Isto gerou a ilusão de que os dois mercados eram articulados diretamente e o desenvolvimento de um deles (pelos mais variados motivos) podia estimular o outro. Logo, se partirmos de uma concepção ampliada de modo de produção - como modo de produção da vida - os estudos dos intérpretes demográficos (sic) podem ser de grande valia para explicar as tensões do feudalismo e o modo como elas possibilitaram a sua crise. 
estritamente separados e a nenhum deles era permitido infiltrar-se no campo indiscriminadamente (POLANYI, 2000, p. 84) ${ }^{20}$.

O que Polanyi denomina aqui por comércio interno (que para ele é sinônimo de "nacional" ou "territorial" (regional para Bernard Slicher Van Bath) é um tipo novo de relação mercantil, específica do capitalismo, pois ela só pode se desenvolver mediante dois processos distintos, mas que começam a interagir de forma sinérgica: a crescente e violenta mercantilização da terra e do trabalho, aliada ao desenvolvimento progressivo de uma nova rede de transportes, capaz de interligar os mercados locais às trocas internacionais, e desse modo, constituir o mercado capitalista ${ }^{21}$.

Portanto, nesse sentido, o desenvolvimento destes "mercados internos" deve ocupar um papel de destaque na explicação sobre a formação do capitalismo Um pouco antes, ressaltei a distinção entre os vários mercados tendo em vista a relação entre a estratificação social e os mecanismos de distribuição do produto social. Mas é possível fazer tal diferenciação nos termos propostos por Polanyi, que sempre apontou a necessidade fundamental de marcar a diferença entre comércio de longa distância (por vezes denominado carrying trade), comércio local e comércio

\footnotetext{
20 Fernand Braudel, ao refletir sobre o que permitiu que as manufaturas e a fábrica - muito minoritárias suplantassem o Verlagssytem, incide neste mesmo ponto: "Nem por isso [o seu número relativamente reduzido] as manufaturas deixaram de ser modelos e instrumentos de progresso técnico. E a cota-parte modesta da produção manufatureira prova mesmo assim uma coisa: as dificuldades encontradas pela pré-indústria no contexto em que se desenvolve. É para romper esse círculo que o Estado mercantilista intervém tantas vezes; que financia e conduz uma política nacional de industrialização" (1996, p. 290).

${ }^{21}$ Este aspecto mostra o vínculo entre a acumulação primitiva de capitais e gestação do capitalismo como um modo de produção necessariamente articulado a um mercado mundial. Em uma conhecida passagem de A Ideologia Alemã, Marx e Engels, ao comentarem a formação do Estado e sua relação com a constituição da Sociedade Civil, destacam esse aspecto: "Ora, quanto mais no curso desse desenvolvimento se expandem os círculos singulares que atuam uns sobre os outros, quanto mais o isolamento primitivo das nacionalidades singulares é destruído pelo modo de produção desenvolvido, pelo intercâmbio e pela divisão do trabalho surgida de forma natural entre as diferentes nações, tanto mais a história se torna história mundial, de modo que, por exemplo, se na Inglaterra é inventada uma máquina que na Índia e na China tira o pão a inúmeros trabalhadores e subverte toda a forma de existência desses impérios, tal invenção torna-se uma fato histórico-mundial; ou pode-se demonstrar o significado histórico-mundial do açúcar e do café no século XIX pelo fato de que a falta desse produto, resultado do bloqueio continental napoleônico, provocou a sublevação dos alemães contra Napoleão e, foi, portanto, a base real das gloriosas guerras de libertação de 1813. Segue-se daí que essa transformação da história em história mundial não é um mero ato abstrato da 'autoconsciência' do espírito mundial ou de outro fantasma metafísico qualquer, mas sim uma ação plenamente material, empiricamente verificável, uma ação da qual cada indivíduo fornece a prova, na medida em que anda e para, come e se veste" (2007, p. 40, grifos meus). Esta citação explicita o que é essencial: não somente a tendência ao expansionismo, mas, sobretudo, a necessidade que o modo de produção capitalista tem de destruir as formas de vida social que ele coloniza, para poder absorvê-las. Um segundo trecho é bastante elucidativo: "Depende exclusivamente da extensão do comércio se as forças produtivas obtidas numa localidade, sobretudo as invenções, perdem-se ou não para o desenvolvimento posterior. Na medida em que não existe ainda comércio para além da circunvizinhança, cada invenção tem de ser feita separadamente em cada localidade, e meros acasos, tais como a irrupção de povos bárbaros, até mesmo as guerras habituais, são o bastante para fazer com que um país com forças produtivas e necessidades desenvolvidas seja forçado a recomeçar tudo novamente, a partir do início (...) Somente quando o intercâmbio mundial tem por base a grande indústria, quando todas as nações são levadas à luta da concorrência, é que está assegurada a permanência das forças produtivas já alcançadas” (2007, p. 55)
} 
"interno", mas tendo como referência a variação nas "formas de integração" e nos tipos de mercado:

Como sabemos num estágio posterior os mercados se tornaram predominantes na organização do comércio exterior. Entretanto, do ponto de vista econômico, os mercados externos são algo inteiramente diferente, tanto dos mercados locais quanto dos mercados internos. Eles não diferem apenas em tamanho; são instituições de funções e origens diferentes. O mercado externo é de "carreação" [A edição brasileira traduz, equivocadamente, carrying por "transação"; a palavra carreação, embora hoje de pouco uso, é a mais adequada] "A troca de lãs inglesas por vinhos portugueses constitui um exemplo. O comércio local é limitado às mercadorias da região, as quais não compensa transportar porque são de demasiado pesadas, volumosas ou perecíveis. Assim, tanto o comércio exterior quanto o local são relativos à distância geográfica, sendo um confinado às mercadorias que não podem superá-la e outro às que podem fazê-lo. Um comércio desse tipo é descrito corretamente como complementar. A troca local entre cidade e campo e o comércio exterior entre diferenças climáticas baseia-se nesse princípio. Um tal comércio não implica competição necessariamente, e se a competição levasse à desorganização do comércio não haveria contradição em eliminá-la. Em contraste com o comércio externo e o local, o comércio interno, por seu lado, é essencialmente competitivo. Além das trocas complementares, ele inclui um número muito maior de trocas nas quais mercadorias similares, de fontes diferentes, são oferecidas em competição uma com as outras. Assim, somente com a emergência do comércio interno ou nacional é que a competição tende a ser aceita como princípio geral do comércio (POLANYI, 2000, p. 80-1).

Mas isto sem se descuidar da interligação - mediada pela tensão política entre as estruturas estatais e recomposição das forças sociais - entre todos estes mercados no nível mais geral, isto é, na escala da economia-mundo em consolidação ${ }^{22}$.

Mas, para retornar ao tema anteriormente em pauta, é necessário ressaltar o modo como a estrutura de privilégios típica das cidades, inicialmente, bloqueava o contato entre o comércio de longa distância e os mercados locais. Como já foi feito

\footnotetext{
${ }^{22}$ Caso contrário, a discussão regride para a noção de "múltiplas transições", onde cada sistema político "nacional" tem a sua via própria, e que se processa predominantemente de acordo com as características "internas" (o curioso é que, nesta linha de interpretação, nunca fica claro, exatamente, o que é interno e externo). Nestes moldes, no que diz respeito à transição, toda a discussão fica girando em torno da especificidade da Inglaterra (e daí se infere os motivos do "fracasso" da Holanda, Portugal etc.). A noção de forças internas e externas só faz sentido com referência ao sistema capitalista, que deve ser a unidade de análise. Logo, o modo como empregamos a noção de "mercado interno" é distinta, e pensada à luz da transição ao capitalismo. Neste caso em particular, a expressão "mercado interno" se opõe - logicamente - ao mercado local e ao mercado de longa distância. O seu desenvolvimento envolve a dissolução e rearticulação destes dois outros mercados - até então segmentados - a um mercado regido pela lógica capitalista. Este processo geral se manifesta de forma peculiar nas diversas regiões que integram a economia-mundo.
} 
referência, as cidades continham estes dois tipos de mercado, mas os mantinham separados. Isolar os mercados urbanos do alcance dos mercadores estrangeiros que, portanto, não tinham acesso ao mercado varejista dos burgos - era do interesse imediato dos burgueses. Os burgueses podiam usar o seu poderio militar e sua autonomia política contra os camponeses das redondezas, caso quisessem elevar o seu grau de exploração, dentro dos limites impostos pela capacidade de resistência dos camponeses (o que, mais uma vez, gerava uma alternativa à "exploração pelo mercado"23, a qual Brenner chamou, de forma meio desastrada, de "acumulação política"). Mas este poder não poderia ser usado desta forma contra os mercadores estrangeiros e, como diz Polanyi, "seus métodos de comércio atacadista capitalista": o máximo que podiam fazer era institucionalizar a separaşão entre os mercados, para proibir que os mercadores internacionais vendessem a varejo e, deste modo, preservar seu papel de intermediário em escala local.

As regulações das guildas, por sua vez, garantiam de forma ainda mais profunda a separação entre estes mercados, mas de forma peculiar:

No que diz respeito aos artefatos industriais, a separação entre o comércio local e o de longa distância era ainda mais profunda, pois neste caso toda a organização da produção para exportação era afetada. A razão disto estava na própria natureza das guildas e corporações artesanais, nas quais se organizava a produção industrial. No mercado local, a produção era regulada de acordo com as necessidades dos produtores, restringindo a produção a um nível remunerativo. Este princípio não se aplicava, naturalmente, às exportações, onde os interesses dos produtores não estabeleciam limites à produção. Em consequência, enquanto o comércio local era estritamente regulado, a produção para exportação da época era apenas formalmente controlada pelas corporações de artesãos (POLANYI, 2000, p. 85).

Exatamente aí reside a peculiaridade da cidade medieval: ela representou tanto um ponto de apoio quanto uma forma de reação à ameaça do capital mercantil, que poderia desintegrar as instituições sociais urbanas ${ }^{24}$ e comprometer o poder do patriciado urbano.

\footnotetext{
${ }^{23}$ Uma coisa é lutar pelo aumento dos privilégios e pressionar para a intensificação das exações feudais. Outra, muito mais explosiva, é lutar para incorporar a terra e a força de trabalho ao mercado. Isto promove necessariamente uma revolução nas formas de vida e nas estruturas do cotidiano, que transforma essencialmente a sociedade.

24 “A cidade medieval típica não tentou evitar o perigo" [de dissolução das instituições urbanas] "diminuindo o abismo entre o mercado local controlável e as incertezas de um mercado de longa distância incontrolável, mas, ao contrário, enfrentou o perigo reforçando com o máximo rigor aquela política de exclusão e proteção que era a rationale de sua existência" (POLANYI, 2000, p. 85-6). Este ponto foi explorado fartamente por Pirenne, em sua polêmica contra Karl Bücher e Werner Sombart: "Estou muito longe de afirmar que o capitalismo exerceu uma influência preponderante sobre o caráter da organização econômica do século doze ao quinze. Eu acredito que,
} 
Polanyi, a partir desta observação acurada e contundente, aponta como, no limite, a cidade - ou melhor, a "burguesia" - levantou diversos obstáculos à pressão do "atacadista capitalista" que, caso pudesse, tentaria unificar os diversos mercados, subordinando-os aos seus interesses ${ }^{25}$. Mas, como já foi apontado, havia uma brecha importante: o comércio de exportação de produtos manufaturados estava fora das restrições típicas das atividades voltadas ao mercado local. Além disto, tendencialmente, esta produção buscava ganhos de escala (tanto nas oficinas, mas principalmente na integração com a produção domiciliar e o Verlagssystem) e outras formas de redução dos custos, além de, em certas etapas, empregar trabalho assalariado. Contudo, para não ficarem suscetíveis à pressão dos mercadores estrangeiros, os mercadores urbanos tendiam a aceitar a separação entre os mercados locais e os mercados de exportação ${ }^{26}$. Mas, enquanto exportadores, a situação era bastante diferente: neste caso, havia um claro interesse em aumentar o volume das operações e ampliar seu raio de ação, interesse que se chocava com as guildas e a organização da produção no campo ${ }^{27}$.

embora não seja correto qualificar essa organização como 'acapitalista' é, por outro lado, correto considerá-la como 'anticapitalista'. Mas afirmar isso é afirmar a existência do capital. Aquela organização" [a cidade medieval] reconhecia a existência do capital desde que ela tentava se defender contra ele, pois, desde o fim do século XIII em diante, ela tomou mais e mais medidas para escapar dos seus abusos. É incontestável que, deste período em diante, ela obteve sucesso pela força legal em diminuir o papel que o capitalismo tinha exercido até aquele tempo. De fato, é certo que o poder do capital foi muito maior durante a primeira parte do período urbano da Idade Média do que no segundo. Mas mesmo no curso do segundo período, se a legislação municipal teve sucesso em de expulsá-lo dos mercados locais, o capital teve sucesso em preservar e em dominar uma bastante considerável porção da atividade econômica. Era o capital que dominava o comércio interlocal, que determinava as formas de crédito e que, ao se fixar em todas as indústrias que produziam não para o mercado da cidade, mas para exportação, vedava a possibilidade de ser controlado, como as demais eram, pelas minuciosas regulações que de inumeráveis formas constrangiam a atividade dos artesãos” (PIRENNE, 1914, p. 497).

25 Nada garante que, caso isso ocorresse, os mercados seriam autorregulados, na acepção de Polanyi. Muito provavelmente eles permaneceriam operando com base na separação entre a produção e a circulação, nos moldes do capital mercantil e, portanto, de forma distinta do que ocorre no capitalismo. Curiosamente, ao refletir sobre os "acertos" do pensamento mercantilista (e, portanto, contra a horda clássica e neoclássica diretamente influenciada pela visão de Smith), Maurice Dobb faz uma observação perspicaz: "Se os mercadores e os mercadoresmanufatureiros estivessem submetidos a uma competição irrestrita, que fontes de lucro lhes restariam? A margem entre o preço de venda e o de compra poderia ser suficiente para cobrir seus custos e, caso não fosse muito desafortunado, lhe garantir uma vida modesta" (...) "Logo, não é surpreendente que, neste período, os lucros fossem concebidos como um fruto da especulação bem sucedida, no sentido de tirar vantagem das diferenças de preço: os lucros desapareceriam rapidamente caso muitos pudessem entrar no ramo de compra e revenda" (...) "Sem a regulação para limitar o número de participantes e proteger a diferença entre o preço de compra e de revenda, o capital mercantil poderia desfrutar de grandes lucros inesperados espasmódicos, mas não poderia ter nenhuma fonte regular de rendimentos" (1950, p. 199-200).

${ }^{26} \mathrm{O}$ fato é que a unificação destes mercados não é o produto da ação de nenhuma classe ou setor de classe específico, mas sim da concatenação de um conjunto de transformações, as quais, situadas em todas as esferas da vida social, passaram a se encadear em torno de pelo menos duas grandes tendências: a acumulação de poder político e de riquezas.

${ }^{27}$ Em um primeiro momento, as políticas "mercantilistas" implementadas pelo poder central contaram com a resistência das cidades e de algumas corporações. Mas, no final das contas, a tendência geral apontava não na abolição, mas na modificação e ampliação da escala da lógica corporativa (POLANYI, 2000, p. 92): as companhias de comércio franqueadas, com o apoio do seu respectivo Estado, passaram a lutar vigorosamente contra suas rivais para monopolizar o mercado atacadista em regiões determinadas do mercado mundial, fato que, além de dar um novo impulso ao capital mercantil, favoreceu a dissolução das instituições típicas das cidades medievais e gerou, 
Portanto, o papel específico das cidades na transição não pode ser exagerado. A cidade tanto freava quanto favorecia o estabelecimento de relações capitalistas de produção, e seu comportamento efetivo - isto é, que conjunto de interesses iria predominar - dependia de diversos fatores, mas um deles se revelou preponderante: a constituição dos Estados modernos, um processo que representou a condensação de um conjunto complexo de forças sociais, com diversas escalas de ação (local, nacional e internacional), e articuladas a vários subsistemas produtivos. No entanto, tendo em vista os problemas privilegiados neste texto, para entender o papel do capital comercial na transição, é fundamental destacar, em termos gerais: i) a forma como o processo de constituição do Estado interagiu com as estruturas urbanas; ii) o modo como o Estado favoreceu a unificação dos diversos mercados em um mercado "nacional" e, essencialmente, como o mercado nacional se integrou ao mercado mundial capitalista em constituição.

Embora tendo outras referências e propósitos, curiosamente, o liberal TrevorRoper ajuda a iluminar a primeira questão. Em termos gerais, a formação das monarquias absolutas altera radicalmente o papel e as formas de organização das cidades. A ascensão do Príncipe era a expressão da consolidação de um mecanismo de poder gigantesco, que desafiava simultaneamente as instituições universalistas $^{28}$ e tinha de incorporar - de forma tensa - os poderes locais. Neste último caso, tratava-se de reduzir o poder local da nobreza (em especial, a imposição direta de prestações e a prerrogativa do uso da força) e destruir a autonomia das cidades. Indiretamente, o jugo do Príncipe sobre as cidades favoreceu ativamente a dissolução das instituições que separavam os diversos mercados e fundamentava o poder do patriciado urbano. Num paradoxo aparente, a construção do Estado Absoluto envolveu a emulação, na escala do reino, de alguns aspectos das formas urbanas de organização ${ }^{29}$. O exército real cuidou de destruir o uso da violência

como tentarei apontar mais a frente, cidades fundadas predominantemente nos monopólios garantidos pelo Estado, tal como, por exemplo, Lisboa.

${ }^{28}$ A ameaça ao Império era direta. A Igreja, por sua vez, reformada ou não, teve de se tornar nacional.

29 Aqui, hipnotizado pelo mito do comedimento "racional" que ele considera típico da civilização urbana medieval, Trevor-Roper deixa escapar uma dimensão importante, ressaltada por Polanyi: esta "expansão" das formas organizacionais urbanas demoliu a separação entre o comércio de longa distância e o comércio local, favorecendo uma integração organizada pelos mercados formadores de preços (autorreguláveis, de acordo com as traduções para o português) que transformou radicalmente a sociedade europeia. A seu ver, o "Estado do Renascimento" foi a perversão de um movimento que nasceu na cidade medieval, e provocou o seu eclipse: "In the Middle Ages the free communes of Flanders and Italy had been the founders of Europe's trade and wealth, the centres of its arts and crafts, the financiers of its popes and kings. The German cities had been the means of colonizing and civilizing the barbarous north, the pagan east of Europe. These cities, moreover, had had their own way of life and had imposed upon Europe some of their own methods of government and standards of value. In its earliest form, the Renaissance itself had been a city phenomenon: it had begun in the cities of Italy, Flanders and south Germany before it was taken over, and changed by princes and popes. And this early Renaissance had the character of the cities within which it was still contained. Like then it was responsible, orderly, self-controlled. For however great their wealth, however splendid their town halls and hospitals, their churches and squares, there is always, in the cities, a trace of calculation and self-restraint. It is the virtue of civic self-government, however oligarchically controlled: a spirit very different from the outrageous, spendthrift, irresponsible exhibitionism of the princes which was to come" (1967, p. 53). A noção de que o progresso social está ligado ao comedimento típico dos mercadores e da população urbana é parte importante da fábula liberal. Trevor-Roper não 
privada da nobreza rural e das cidades, que foram postas sob domínio dos Duques que, naturalmente, estavam do lado do Príncipe. Tratava-se, portanto, de reduzir a autonomia das cidades para tentar garantir a autarquia do Estado.

E, de forma elegante, Trevor-Roper complementa: "Se as cidades esperam crescer agora, deve ser por novos métodos. Não deve ser por meio da independência: estes dias já passaram" $\left(1967\right.$, p. 54) ${ }^{30}$. E o autor prioriza duas formas de crescimento urbano diretamente ligadas ao absolutismo (termo que ele não gosta de empregar). As cidades que sediaram as novas cortes e instituições políticas cresceram acompanhando a expansão da máquina burocrática e a vida suntuosa cortesã, pois a riqueza de toda a nação - articulada pela tendência à centralização dos impostos - era sistematicamente nelas "derramada". A avidez pelo bullión, um elemento fundamental do mercantilismo, por sua vez, criou cidades amparadas nos monopólios reais, cujos principais exemplos seriam Lisboa e Sevilha. A esta visão pode se somar as transformações na economia rural, desprezadas por Trevor-Roper: as cidades que, especialmente na Inglaterra, brotaram da generalização das manufaturas e das fábricas no campo, onde a industrialização originária germinou ${ }^{31}$. Em todos estes casos, a função das cidades e a vida urbana mudou radicalmente, e as pressões que determinaram esta transformação vieram das mais variadas direções.

\section{Considerações Finais}

só afirma isto como, em um elaborado sofisma, atribuiu à um elemento externo - o Príncipe e seu séquito - a marcada tendência ao arrivismo da burguesia.

30 A citação completa, que transcrevo em inglês, para manter melhor o efeito dramático que o autor esperava obter: "For as a rule surrender was the price of continued prosperity: how else could the cities survive, once the princes had discovered the secret of State? By subduing the Church, extending their jurisdiction, mobilizing the countryside, the princes had created a new apparatus of power, "the Renaissance State," with which they could tax the wealth of the cities, patronize and extend their trade, take over and develop their art and architecture. If the cities hope to thrive now, it must be by new methods. It must not be through independence: those days are past. It must be through monopoly, as the sole grantees of princely trade in these expanding dominions; as Lisbon and Seville throve on the grants of the kings of Portugal and Spain. Or they might thrive as centres of extravagant princely consumption, as royal capitals. For in some of the old cities the victorious princes would establish their new courts: courts which sucked up the wealth of the whole country and rained it down on the city of their residence. Essentially the sixteenth century is an age not of cities but of courts: of capital cities made splendid less by trade than by government. It was not as industrial or commercial cities, but as courts, that Brussels, Paris, Rome, Madrid, Naples, Prague achieve their splendour in the sixteenth century. And the brilliance of these courts is not the discreet, complacent self-advertisement of great merchants out of their calculated profits: it is the carefree magnificence of kings and courtiers, who do not need to count because they do not have to earn" $(1967$, p. 54). Embora repleto de insights interessantes, o argumento geral do livro é pouco convincente: a revolução do século XVII teria sido detonada, essencialmente, pelo excessivo parasitismo do Estado (um efeito do excesso de centralização de poder, que exacerbou a tensão entre a Coroa e os mecanismos de representação local), a única causa geral, que provocou respostas peculiares.

31 O principal mérito de Robert Brenner foi ter chamado a atenção para o fato de que a industrialização originária (i.é. britânica) tem raízes rurais. Este argumento não é (e não era na ocasião) novo: ele está contido na obra de Dobb, bem como já tinha sido usado por Hobsbawm (exemplos: 1954, 1969, 1975), mas coube a Brenner explicitar isso novamente na década de 1980. Infelizmente, ao insistir na suposta peculiaridade da Inglaterra como a chave, a este avanço pontual, ele faz a discussão geral regredir, aprisionando-a ao falacioso debate do interno versus externo. 
Analisar a transição um modo de produção a partir do que lhe sucedeu é um procedimento metodologicamente válido, mas nada trivial. Neste texto, tendo como referência principal a dinâmica do capital mercantil, toquei em dois problemas clássicos, que ilustram estas dificuldades: a polêmica sobre as "duas vias" ao capitalismo e a celeuma sobre o papel das cidades na transição. No primeiro caso, o problema foi claramente formulado por Marx em termos lógicos, isto é, no plano das categorias analíticas forjadas para - e, arriscaria dizer, pela análise da dinâmica do capitalismo consolidado. A tentativa posterior de estabelecer vínculos diretos entre alguns momentos de sua reflexão e casos "concretos" - ou "fases" - da transição do feudalismo ao capitalismo é que gerou confusão ${ }^{32}$. As ambiguidades e desentendimentos se agravaram pelo fato destes vínculos terem sido pautados por preocupações particulares muito distintas, tais como, por exemplo, os alinhamentos de classe que levaram à Revolução Inglesa (Dobb) ou a ênfase na centralização de capitais como elemento precursor da Revolução Industrial (Swezzy). Por fim, a discussão acabou sendo reduzida a uma prosaica disputa exegética sobre qual seria o "verdadeiro" significado de algumas passagens da obra marxiana. É evidente que este exercício é necessário, mas não nestes termos. Uma coisa é pensar a formação do capitalismo a partir da gênese de seus elementos constitutivos fundamentais, sob a ótica da sua dinâmica. Outra, bem diferente, é tentar reconstruir a transição do feudalismo ao capitalismo em seus próprios termos, isto é, uma transformação essencialmente descontínua, permeada pelo acaso e por conjunturas singulares, e que envolveu o entrelaçamento das várias esferas da existência social, em suas diversas temporalidades. Para tanto, é a referência geral que precisa mudar: é necessário tomar o feudalismo como um modo de produção articulado, movido por contradições próprias, cuja crise geral deflagrou a transição que, dentre diversos futuros possíveis, possibilitou a formação do capitalismo.

Visto a essa luz, não é somente a questão das "duas vias" que muda de sentido: o papel das cidades na transição também. Em primeiro lugar, as cidades não são "externas" ao feudalismo. Pelo contrário, a sociedade feudal desenvolveu um tipo especial de vida urbana, imersa e determinada, pelo menos em última instância, pelos padrões da vida agrária e das relações de poder que daí emanavam. Ao contrário da visão da idílica Economia Política clássica, a separação entre a cidade

\footnotetext{
32 Um tipo suplementar de confusão, muito influente em certas searas filosóficas, deriva também de um movimento inverso a este: é necessário estabelecer mediações. Até aí nada de novo. Mas, antes disso, é necessário formalizar claramente o sistema filosófico de Marx, de forma reversa, isto é, da lógica da exposição (supostamente expressa nos livros que ele publicou em vida e pôde revisar) para a lógica da investigação. Uma vez (re)construída a unidade lógica do seu pensamento, é possível definir a posição, o alcance e as nuances dos conceitos. Somente a partir daí é possível estabelecer com rigor as mediações. Surgem dois problemas imediatos: um, menos importante, que envolve o papel dos textos "mercenários" (isto é, que Marx escrevia por dinheiro) no seu sistema de pensamento e outro, mas decisivo, que diz respeito aos seus manuscritos. Quais e que trechos devem ser integrados? Com que critérios? Em suma: um debate análogo às disputas entre Judeus, Católicos e Protestantes sobre a origem e a composição da Bíblia Sagrada.
} 
e o campo é muito mais um produto da transição do que uma de suas causas ${ }^{33}$. Enquanto um nódulo do capital mercantil (e tal como ele), a cidade medieval contribui tanto para a preservação da sociedade feudal como para a sua transformação. A crise do feudalismo não é idêntica à formação do capitalismo: mas foi esta crise que, na medida em que se agravou e promoveu transformações radicais, criou as condições para um novo modo de produção que, ao libertar o antediluviano capital mercantil dos seus grilhões, o metamorfoseou radicalmente, criando um novo sistema de exploração, muito mais intenso e voraz dos que os precedentes, em um sentido muito preciso: um modo de produção necessariamente mundial, que não tolera modos de vida social estranhas a ele.

Apêndice - Aqui é importante precisar melhor o significado do termo Burgo. Por conta da influência da obra de Pirenne, por burgo geralmente se entende as cidades - e, muitas vezes, o seu setor administrativo (o patriciado urbano) - que se desenvolveram a partir das zonas comerciais que se aglomeraram, a partir do século XI, em pontos onde o formato da superfície da terra, a profundidade e a direção dos rios permitiram a formação de nódulos comerciais (ele faz referências constantes também, na Gália e Itália, ao povoamento das cidades romanas que não tinham desaparecido), ou então, em volta dos núcleos urbanos feudais primitivos (cidades episcopais, abadias, castelos senhoriais, casas reais, etc.) e demais fortificações.

Os primeiros habitantes - uma classe de "desenraizados" - se reuniram em volta das muralhas do núcleo original e, com o tempo, tenderam a erguer também uma cerca própria (paliçadas de madeira, para repelir assaltantes) ou até mesmo, no caso das cidades mais prósperas, muros e fortificações (custosas muralhas de pedra, por vezes flanqueadas por torres e, portanto, capazes de resistir ao cerco de inimigos organizados). A construção deste segundo muro tornou desnecessário o primeiro e, por envolver um território e um volume populacional muito maior (os núcleos originais eram muito exíguos, e geralmente restritos a residência dos poderosos e a atividades "administrativas" da Igreja), produziram diversas transformações.

$\mathrm{Na}$ "produção", a mais evidente foi a generalização do artesanato e das atividades mediadas pelo dinheiro. No "direito", a principal transformação foi a construção de um novo tipo de autoridade feudal (a cidade enquanto uma espécie de senhorio

\footnotetext{
33 John Merrington é incisivo nisto: "Se tivermos em mente essas origens rurais" [das cidades, e, na realidade, do "Ocidente"] "perceberemos que o industrialismo capitalista implicou não apenas uma transferência maciça de recursos humanos e materiais em favor das concentrações urbanas, mas também uma conquista em relação ao campo, que se torna 'ruralizado', pois no passado ele não representava um ambiente exclusivamente agrícola. Ao se tornar um centro de toda espécie de produção, um setor primário autônomo que incorpora o total da produção social, o campo se transforma em "agricultura", i.é. uma indústria separada de alimentos e matérias-primas, dividida, por sua vez, em vários tipos especializados de cultivo, distritos etc.” (1975, p. 72).
} 
coletivo, administrado pelo Patriciado). Todas estas transformações ocorreram em sincronia com mudanças no sistema "fiscal", cujo eixo básico envolvia o rateio das despesas com a manutenção da muralha e das guarnições. É isto que dá origem ao subúrbio comercial fortificado, que, na linguagem contemporânea, é comum denominar por "novo burgo", por oposição ao "velho burgo", i.é. o núcleo "feudal" originário (que, sintomaticamente, Pirenne define em função do seu isolamento das redes comerciais). O termo mais usado na época era fauburg/forisburgus (fora do burgo).

Por cidade, ou mesmo burgo, portanto, se entende esta articulação formada na grande expansão iniciada no século XI. E por burguês, o habitante destas novas unidades. É exatamente o destino e os desdobramentos deste subúrbio comercial que está no centro das preocupações de Pirenne, que tende a atribuir tanto a gênese como o desenvolvimento das cidades à reativação das grandes rotas comerciais (uma tese muito combatida, mas nem sempre analisada nos termos do autor). Por extensão (e de forma dedutiva, pois há pouca documentação para sustentar essa dimensão do seu raciocínio), Pirenne destaca o papel dos grandes mercadores e artesãos na condução das cidades (e, portanto, na constituição do patriciado urbano). A palavra burguesia - que o próprio Pirenne reconhece que não era de uso corrente (a palavra civis era mais empregada) - foi criada por estes novos homens, para se identificarem e, sugere, Pirenne, para se diferenciarem dos habitantes do "velho" burgo, que tendiam a ser chamados de castrenses ou castelanni. O problema é que Pirenne exagera na distinção do velho e do novo burgo, assim como não oferece evidências suficientes para o seu argumento de que a população do "novo burgo" - que ele também, ocasionalmente, chama de "classes médias", compostas de "desenraizados" sedentos por liberdade - era predominantemente composta por mercadores e artesãos. É possível suspeitar também do peso a eles atribuído por Pirenne na formação do patriciado e, principalmente, do seu protagonismo na regeneração da vida urbana. A. S. Hibbert (1953), em artigo clássico, questiona estes elementos da interpretação de Pirenne. Ele aponta como muitas familias tradicionais do "velho burgo" conseguiram se adaptar às transformações do meio urbano, usando do seu poder tradicional para conseguir benefícios no novo contexto econômico. "Dois processos estão envolvidos na formação do patriciado, a transformação interna de uma velha classe dominante e o recrutamento de novas famílias dentre os mercadores e artesãos mais bemsucedidos, que geralmente eram imigrantes ou descendentes de imigrantes" (1953, p. 23). Logo, o processo que deu origem à burguesia - no sentido que Pirenne quer atribuir ao termo - é duplo: envolve a absorção dos mercadores e artesãos que enobrecem pelo sucesso de suas atividades $e$ a transformação interna "de uma classe dominante que já existia, e foi suficientemente oportunista para mudar a ênfase de suas atividades à medida em que as condições mudavam” (p. 24). É evidente que muitos dos habitantes tradicionais da cidade eram conservadores demais para se mesclarem e, portanto, tendiam a rejeitar os mercadores e, até 
mesmo, os seus pares mais propensos a usar o seu poder para lucrar com as "novas" atividades comerciais. Portanto, o recrutamento dos Homens Novos às camadas superiores podia significar tanto uma válvula de escape quanto uma ponderosa fonte de conflitos. "Forasteiros, e especialmente aqueles mercadores e artesãos mais competentes e que exploraram melhor sua habilidade e boa fortuna, podiam e adentrar e adentraram no patriciado. Este recrutamento podia tomar duas vias principais. Havia um fluxo contínuo e regular dos novos ricos ao grupo no poder, cuja assimilação era favorecida quando o próprio patriciado possuía interesses comerciais significativos. A taxa de recrutamento, contudo, podia variar bastante e dependia particularmente das atitudes do próprio patriciado. Isto sugere a segunda via. Se o grupo dominante se mostrasse inadaptável e exclusivista, uma classe de noveaux riches tendia a se formar por oposição ao grupo no poder, particularmente quando as condições econômicas possibilitavam novas formas de obtenção de riqueza. O recrutamento neste caso, por assim dizer, sai pela culatra e, portanto, produz tensões e crises variáveis, onde os novos homens são impelidos a lutar para tomar ou poder ou, pelo menos, para compartilhar com os mais antigos" (1953, p. 25). Logo, as cidades não exerceram um papel homogêneo e linear na transição e, muito menos, podem ser concebidas como "microcosmos" do capitalismo.

\section{Referências}

ANDERSON, Perry. Lineages of absolutist State. Londres: New Left Books, 1974.

BRAUDEL, Fernand. Civilização material, economia e capitalismo: os jogos das trocas. São Paulo: Martins Fontes, 1996.

DOBB, Maurice. Studies in the development of capitalism. Londres: Routledge \& Kegan Paul, 1950.

HIBBERT, A. S. The origins of medieval town patriciate. Past and Present, n. 3, 1953.

HOBSBAWM, Eric. The age of capital. Nova York: Widenfeld \& Nicolson, 1975.

HOBSBAWM, Eric. Industry and empire. Baltimore: Penguin Books, 1969.

HOBSBAWM, Eric. The general crisis of the European economy in the XVII century. Past and Present, n. 5, 1954. 
MARX, Karl. The capital (vol. III). Londres: Penguin Books, 1991.

MARX, Karl. O capital: crítica da economia política (vol. IV). São Paulo: Nova Cultural, 1988.

MARX, Karl; ENGELS, Friedrich. A ideologia alemã. São Paulo: Boitempo, 2007.

MERRINGTON, John. Town and country in the transition to capitalism. New Left Review, I/93, 1975.

NEF, John. Industry and government in France and England, 1540-1640. Filadélfia: The Society, 1940.

PIRENNE, Henri. Medieval cities: their origins and the revival of trade. Princeton: Princeton University Press, 1946.

PIRENNE, Henri. The stages in the social history of capitalism. The American Historical Review, 19 (3), 1914.

POLANYI, Karl. A subsistência do homem e ensaios correlatos. Rio de Janeiro: Contraponto, 2012.

POLANYI, Karl. A grande transformação. Rio de Janeiro: Campus, 2000.

STEVENS-COX, Gregory. St. Peter Port, 1680-1830: the history of an international Entrepôt. Suffolk: Boydel \& Brewer, 1999.

TREVOR-ROPER, Hugh. The crisis of the seventeenth century: religion, the reformation and social change. Indianapolis: The Liberty Fund, 1967.

Endereço para correspondência:

Eduardo Barros Mariutti - eduardomariutti@gmail.com

Rua Pitágoras, 353 - Barão Geraldo

13083-857 Campinas/SP, Brasil 